\title{
The Role of the Cephalopod Digestive Gland in the Storage and Detoxification of Marine Pollutants
}

\author{
Ana P. Rodrigo and Pedro M. Costa * \\ Environmental Toxicology Lab, MARE - Marine and Environmental Sciences Centre, Departamento de Ciências e Engenharia \\ do Ambiente, Faculdade de Ciências e Tecnologia da Universidade Nova de Lisboa, Caparica, Portugal
}

OPEN ACCESS

Edited by:

Giovanna Ponte,

CephRes and SZN, Italy

Reviewed by:

Paco Bustamante,

University of La Rochelle, France

Fuencisla San Juan,

University of Vigo, Spain

Carlos Rosas,

Universidad Nacional Aitonoma De

Mexico, Mexico

*Correspondence:

Pedro M. Costa

pmcosta@fct.unl.pt

Specialty section:

This article was submitted to Invertebrate Physiology,

a section of the journal

Frontiers in Physiology

Received: 01 February 2017 Accepted: 03 April 2017

Published: 20 April 2017

Citation:

Rodrigo AP and Costa PM (2017) The Role of the Cephalopod Digestive Gland in the Storage and Detoxification of Marine Pollutants.

Front. Physiol. 8:232.

doi: 10.3389/fphys.2017.00232
The relevance of cephalopods for fisheries and even aquaculture, is raising concerns on the relationship between these molluscs and environmental stressors, from climate change to pollution. However, how these organisms cope with environmental toxicants is far less understood than for other molluscs, especially bivalves, which are frontline models in aquatic toxicology. Although, sharing the same basic body plan, cephalopods hold distinct adaptations, often unique, as they are active predators with high growth and metabolic rates. Most studies on the digestive gland, the analog to the vertebrate liver, focused on metal bioaccumulation and its relation to environmental concentrations, with indication for the involvement of special cellular structures (like spherulae) and proteins. Although the functioning of phase I and II enzymes of detoxification in molluscs is controversial, there is evidence for CYP-mediated bioactivation, albeit with lower activity than vertebrates, but this issue needs yet much research. Through novel molecular tools, toxicology-relevant genes and proteins are being unraveled, from metallothioneins to heat-shock proteins and phase II conjugation enzymes, which highlights the importance of increasing genomic annotation as paramount to understand toxicant-specific pathways. However, little is known on how organic toxicants are stored, metabolized and eliminated, albeit some evidence from biomarker approaches, particularly those related to oxidative stress, suggesting that these molluscs' digestive gland is indeed responsive to chemical aggression. Additionally, cause-effect relationships between pollutants and toxicopathic effects are little understood, thus compromising, if not the deployment of these organisms for biomonitoring, at least understanding how they are affected by anthropogenically-induced global change.

Keywords: aquatic toxicology, mollusca, Cephalopoda, biomarkers, toxicological pathways, bioaccumulation

\section{INTRODUCTION}

Cephalopods are a particular group of invertebrates that share many important features with highorder animals as a result of convergent evolution, with emphasis on nervous system function. These features are, nonetheless, analogs to those of chordates, as cephalopods hold the basic molluscan body plan. Molluscs, however, form a cunningly diverse group of animals, ranging from sedentary filter feeders like bivalves to the giant predator squid Architeuthis. Among predators, cephalopods are of special interest in terms of anthropogenic impacts onto food webs, as they feed on a wide range of live prey and have high growth and metabolic rates (see Mangold, 1983), which poses important questions regarding bioaccumulation and tolerance to chemical 
stressors. However, the physiological and molecular mechanisms underlying toxicopathological effects and detoxification processes in cephalopods are not well understood, albeit the importance of other molluscs, especially bivalves, in biomonitoring and substance testing. Overall, most studies concerning exposure of cephalopods to marine contaminants relate to the accumulation of trace elements, in most cases being limited to commercial species (see Penicaud et al., 2017).

It is suggested that storing metals in various tissues can be an important strategy to cope with metal toxicity (see Miramand and Bentley, 1992; Bustamante et al., 2000; Raimundo et al., 2005 plus the recent review by Penicaud et al., 2017). This efficient strategy, which likely minimizes energetic costs, is seemingly common among Nautiloid and Coleoid cephalopods (Bustamante et al., 2000). However, the mechanisms involved even in these basic processes are not fully resolved, particularly in the case of organic contaminants. This gap noticeable for invertebrates in general, bivalves included, albeit the attention the digestive gland has been receiving as target for bioaccumulation and biomarker analysis for being the analog the vertebrate liver. While there is indication that detoxification and excretion processes may indeed occur with the assistance of specialized cells (Costa et al., 2014), this issue is not entirely consensual as the digestive gland is able to provide long-term storage of both toxic and essential metals, such as $\mathrm{Cd}$ and $\mathrm{Zn}$ (Bustamante et al., 2002b) The growing level of genomic annotation for bivalves and a few cephalopods also indicates that CYP-like enzymes and respective organic xenobiotic pathways are active in molluscs (Cheah et al., 1995).

As such, the present review aims at summarizing the stateof-the-art on the role of digestive gland in the detoxification of organic and inorganic contaminants in cephalopods, emphasizing the comparative microanatomy, physiology, and molecular processes among various groups of molluscs that, however, indicate that toxicological pathways in cephalopods may be more diverse and complex than anticipated.

\section{FORM AND FUNCTION OF THE CEPHALOPOD DIGESTIVE GLAND}

The molluscan digestive gland is a multi-task annex to the digestive tract, involved in secretion of digestive enzymes, extraand intracellular digestion, substance storage and excretion (Bidder, 1966). As in many invertebrates, organs are called to perform multiple functions due to reduced differentiation comparatively to vertebrates. The basic structure of the digestive gland is well-conserved among molluscs, being formed by blindend indigitations called "tubules" or more accurately, diverticula, being connected to the gut (specifically to the caecum, in cephalopods) by ducts (Budelmann et al., 1997). Refer to Figure 1 for a comparative overview of the molluscan digestive gland. In cephalopods, albeit the lack of an absolute consensus, three distinct cells types have been identified. Digestive cells are the most abundant, followed by basal (replacement) and the more elusive excretory cells, characterized by a single, large hydropic vacuole that may bear mineral precipitates. Note that basal cells are commonly termed crypt and basophilic cells in gastropods and bivalves, respectively. Although demonstrated in cephalopods (e.g., Boucaud-Camou, 1968; Costa et al., 2014), the existence of specialized excretory cells is not consensual in other molluscs and their specific function in cephalopods is not well understood. There are, nonetheless, reports on changes in size and number of hydropic vacuoles of digestive gland cells of gastropods and bivalves as a result of exposure to mixed metallic and organic toxicants (Zaldidar et al., 2007; Lobo et al., 2010).

Cephalopod digestive gland epithelia are more complex than other molluscs' with respect to specialized endosomes. In fact, structures such as "boules" (vacuoles involved in digestion and enzyme secretion) and "brown bodies" (excretion of crystalline salts and amorphous materials) are seemingly exclusive. The lack of detailed studies integrating digestive gland histology and cytology with molecular pathways, as well as the lack of comparative studies between molluscan taxa hinders understanding how molluscs evolved to handle hazardous substances.

Accumulation of toxicants in the digestive gland depends on their mechanisms of apical entry. Bustamante et al. (2002b) revealed that $\mathrm{Cd}$ and $\mathrm{Zn}$ enter the cephalopods' digestive gland directly via food and indirectly via blood, in the latter case if uptake occurs from seawater. Nonetheless, the same authors disclosed that the elimination of these metals is faster if uptaken through water. It must be noted that the existence of a closed circulatory system in these molluscs, likely render the organ particularly efficient for nutrient absorption and as a filtering system for peripheral fluids. Indeed, unlike bivalves for instance, the cephalopod digestive gland possesses an intricate network of arteriole-like blood vessels (e.g., Swift et al., 2005; Costa et al., 2014). To these features is added the ability to form (and eventually release) mineral corpuscles called spherulae (spherocrystals) in the basal cells, first noticed by Martoja and Marcaillou (1993) and more recently described by Costa et al. (2014) which may thus have an important role in metal homeostasis, similarly to what has been suggested for some gastropods (Volland et al., 2012).

The first descriptions of the microstructure of the cephalopod digestive gland are almost as old as histology itself (refer to the pioneer works by Frenzel, 1886 and Cuénot, 1907). These were complemented by important histochemical descriptions being made from the 1960s onward that favored structural and digestion-related aspects (e.g., Boucaud-Camou, 1968; Semmens, 2002; Martinez et al., 2011). However, even for bivalves, which are the most investigated invertebrates by toxicologists, there are many gaps about the relation between form and function of the digestive gland and toxicant metabolism.

\section{THE DIGESTIVE GLAND IN BIOACCUMULATION AND DETOXIFICATION OF METALS}

The vast majority of literature focusing on toxicants in cephalopods relates to metals, as cephalopods are known to bioaccumulate impressive amounts of hazardous elements, like $\mathrm{Cd}$, albeit others, such as $\mathrm{Hg}$, appearing to be less significant, 

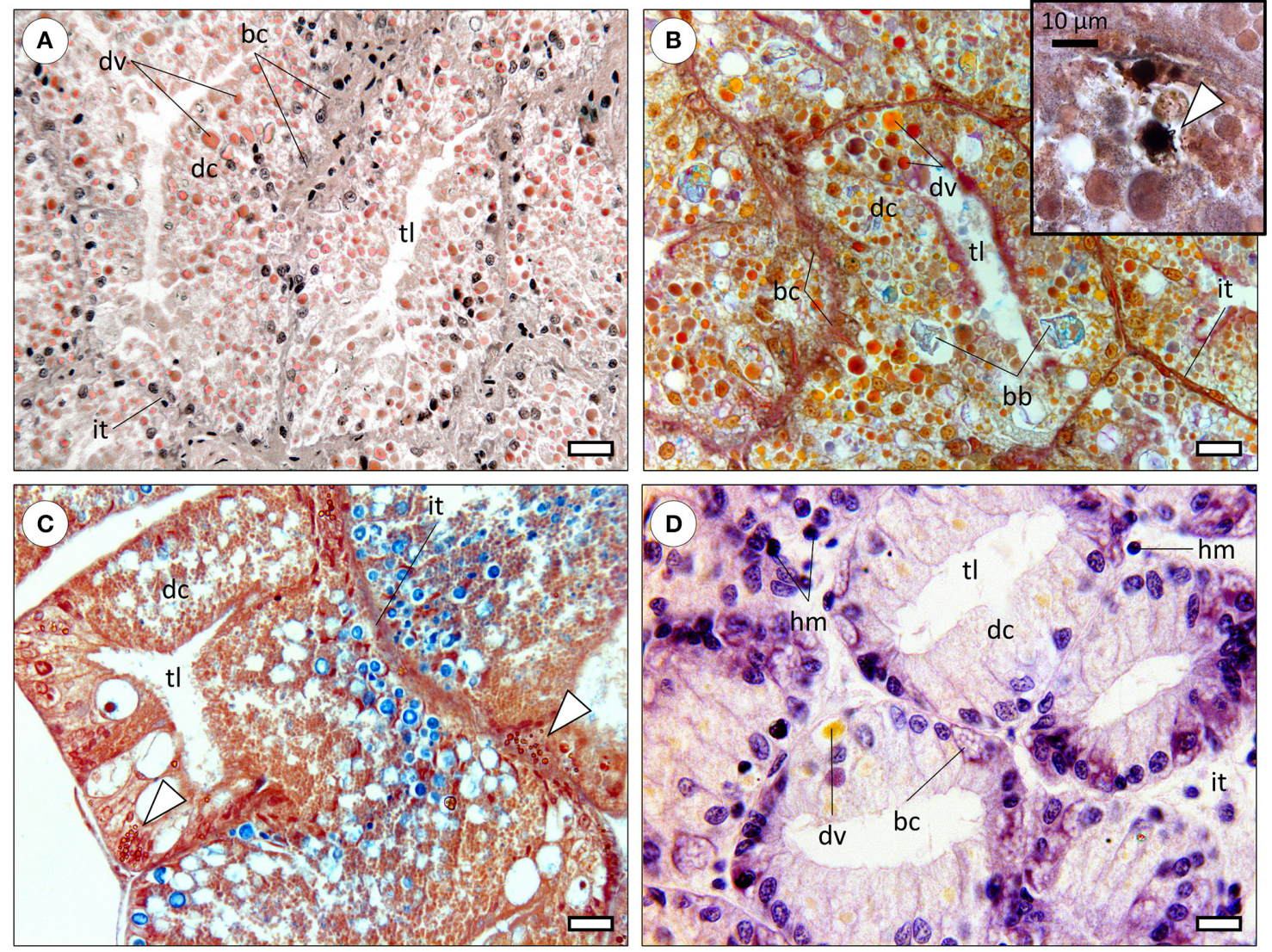

FIGURE 1 | Comparative histology of the molluscan digestive gland (paraffin sections). bc, basal cells (also called replacement; crypt, basophilic or pyramid cells); dc, digestive cells; dv, digestive vacuoles; hm, haemocytes; it, intertubular tissue; tl, tubule lumen. (A) Digestive gland of the common octopus (Octopus vulgaris) evidencing large digestive tubules (diverticula) formed mostly by digestive cells. The distinctive digestive vacuoles of cephalopods are naturally pigmented and traditionally referred by the French term "boules." Haematoxylin \& Eosin. Scale bar: $25 \mu \mathrm{m}$. (B) Micrograph of the digestive gland of a cuttlefish (Sepia officinalis), showing a similar structure to that of Octopus. Brown bodies (bb) are distinctive of sepioids, being comprised of amorphous, undigested, materials. Tetrachrome stain. Scale bar: $25 \mu \mathrm{m}$. Inset: Basal cells were observed to hold calcic spherulae that include other metals as well, embedded in a proteinaceous matrix but the issue needs further research. The presence of calcium in spherulae in basal cells is here determined histochemically (stained black) through the von Kossa reaction, counterstained with Nuclear Fast Red (arrowhead). (C) Section through the digestive gland of the marine gastropod Onchidella celtica (Pulmonata), evidencing a similar structure and to that of cephalopods, albeit differences in the histochemical signal of digestive vacuoles, here predominantly blueish (from sugars), likely due to the herbivore feeding regime. The staining is similar to that of the preceding panel. The specimen was fixated in Zenker's solution, which contains (potassium) bichromate that reacts with metallic compounds originating yellow-orange deposits (arrowheads), once again visible in basal cells. Scale bar: $25 \mu \mathrm{m}$. (D) Section across the digestive gland of a bivalve (Ruditapes decussata), stained with Haematoxylin and Eosin. The tubules are smaller than previous examples and digestive cells less intricate with respective to variety, quantity and natural coloration of digestive vacuoles, regardless of digestive phase (which is similar among all panels). Basal cells are again evident and bear vesicular-like structures, potentially spherulae or similar. Note the wider and sparser intertubular tissue within which haemocytes can be found, as bivalves have an open circulatory system. Scale bar: $12 \mu \mathrm{m}$.

which indicates metal- and organ-specific pathways (Penicaud et al., 2017). It has been shown that the digestive gland holds the highest concentrations of essential (like $\mathrm{Cu}$ and $\mathrm{Zn}$ ) and non-essential (such as $\mathrm{Ag}, \mathrm{Cd}$ and $\mathrm{Pb}$ ) metals in several cephalopods, with emphasis on Sepia and Octopus, comparatively to other organs, mantle and arms included, the latter of which raise particular concerns regarding human consumption (e.g., Raimundo et al., 2004, 2005; Seixas et al., 2005; Bustamante et al., 2006; Pereira et al., 2009). However, the digestive gland has been identified as the main metal accumulation organ even in the Nautiloidea (Pernice et al., 2009). Available data suggests that the cephalopod digestive gland is particularly efficient in the retention of these elements, likely as a function of chelating agents, especially proteins. In fact, there have been a few works that related concentrations of metals in this organ with different types of largely undisclosed proteins distributed through several subcellular partitions. For instance, Raimundo et al. (2010a) noticed that, in the common octopus, $\mathrm{Pb}$ was associated to unknown high molecular weight proteins while $\mathrm{Zn}, \mathrm{Cu}$ and $\mathrm{Cd}$ showed high affinity to both high and low molecular weight proteins. Somewhat similar associations were recorded in the digestive glands of red arrow squid (Nototodarus gouldi) by Finger and Smith (1987) and in the common cuttlefish by Bustamante et al. (2006). These authors suggested that 
these associations may relate to different metal detoxification mechanisms, in many cases likely modulated by metal burden per se, through the induction of chelating proteins. Interestingly, Costa et al. (2014), demonstrated histochemically that the metalcontaining spherulae in cuttlefish digestive gland basal cells are formed by a matrix of proteinaceous materials, being released into the lumen of tubules as cells differentiate. However, there seems to be some selectivity in the accumulation of metals in spherulae. Unlike $\mathrm{Cu}$, which appears to be accumulated mostly in these structures, $\mathrm{Fe}$ accumulates essentially in the cytosol of digestive cells, which has been confirmed histochemically in the independent works by Martoja and Marcaillou (1993) and Costa et al. (2014) with Sepia officinalis. Altogether, basal cell spherulae may be common in molluscan digestive glands, even though their role and formation is not well understood. Volland et al. (2012), for instance, demonstrated the existence of these structures in basal cells in the marine gastropod Strombus, albeit being seemingly not involved in $\mathrm{Cd}$ bioaccumulation upon induced exposure. In agreement, Bustamante et al. (2002a) reported that, in several different cephalopods, $\mathrm{Cd}$ is mostly cytosolic.

It has also been suggested that metallothioneins (MTs), well described in bivalves, play an important role in the formation of spherulae (Martoja and Marcaillou, 1993). However, in cephalopods, MT induction in the digestive gland may not be entirely consistent with exposure to metals, even in the case of exposure to strong inducers such as Cd (Bustamante et al., 2002a; Raimundo et al., 2010b; Rodrigo et al., 2013). It is possible that elements such as $\mathrm{Cd}$, are not involved in detoxification via spherulae (thus remaining in the cytoplasmic fraction), which in its turn, relies on MT and, potentially, unknown high molecular weight proteins (see Penicaud et al., 2017 , for a summary). This interesting perspective, indicates that there can be novel mechanisms of toxicity and detoxification of non-essential metals like $\mathrm{Cd}$ in cephalopods that need to be unraveled. As such, the known mechanisms for MT expression, described essentially for vertebrates, namely those relying on metallothionein transcription factor (MTF) mediation may not apply entirely or at all. In Table $\mathbf{1}$ are summarized the most relevant among the very few publications on biomarker responses in cephalopod digestive gland in an ecotoxicological context, which includes also the MT response as potential indicator of exposure to metals.

\section{EVIDENCE FOR THE METABOLISM OF ORGANIC TOXICANTS}

Although far less common than for metals, some studies addressed the issue of bioaccumulation of various organic hazardous substances in the cephalopod digestive gland, from polycyclic aromatic hydrocarbons (PAHs) and polychlorinated biphenyls (PCBs) to amnesic shellfish toxin (Costa et al., 2005, 2009; Danis et al., 2005; Storelli et al., 2006; Semedo et al., 2014). Nevertheless, the pathways of detoxification and elimination of organic substances, pollutants and toxins (endogenous or exogenous) that are called bioactive compounds are strikingly more complicated than metal chelation and expression of chelators. These mechanisms have been described mostly for mammals and are not consensual for invertebrates, once again indicating important knowledge gaps, in spite of the relevance of molluscs for ecotoxicologists.

The pathways for drug metabolism, meaning phases I (biotransformation) and II (conjugation), to which is now added a phase III (elimination) have been described in the vertebrate liver (see Ferreira et al., 2014, and references therein). Their functioning in invertebrates is not entirely consensual, in part due to the differential response of common biomarkers between vertebrates and invertebrates. For instance, one of the most important systems involved in phase I, the cytochrome P450 (CYP) monooxygenase complex (involved in the detoxification of many bioactive xenobiotics), has long been shown to hold similarities between invertebrates and vertebrates using cDNA probes and Western blotting techniques (Livingstone, 1994). This includes evidence that at least some octopodid cephalopods express CYP isoenzymes, albeit at reduced levels comparatively to vertebrates (Cheah et al., 1995). The CYP systems are localized mainly in the microsomes of the digestive gland cells of molluscs, although it was also found in other tissues like gills and even in haemocytes (Oehlmann and Schulte-Oehlmann, 2003). Still, the relevance of CYP1A in molluscs (involved in the metabolism of important PAHs, polychlorinated biphenyls and dioxins, as examples) has been disputed through works with bivalves, in favor of other forms, such as CYP4 (Chaty et al., 2004). In contradiction, there is some evidence for CYP1A activity and induction in terrestrial molluscs exposed to toxicants (Snyder, 2000, for a review). It is also important to mention that the pathways leading to increased CYP expression, usually involving xenobiotic-activated nuclear receptors (XANRs), are not well understood in invertebrates (see Richter and Fidler, 2014). In fact, the cephalopod equivalent for the aryl hydrocarbon receptor (Ahr) pathway, which is responsible for increased expression of CYP1A by PAHs and similar in vertebrates, remains a mystery. Still, there are promising findings with bivalves regarding its expression in gills and digestive glands exposed to Ahr agonists like benzo[a]pyrene (e.g., Châtel et al., 2012).

Schlenk and Buhler (1988) suggested that CYPs are more important in the metabolism of endogenous substrates rather than xenobiotic metabolism in Polyplacophora digestive glands, whilst other works evidenced some induction in bivalves (concerning enzyme content and activity) by agents ranging from pharmaceuticals to acrylamide, although unable to metabolize compounds that can be biotransformed in vertebrates or induced in a reduced extent (see for instance Galli et al., 1988; Larguinho et al., 2014). Also, Cheah et al. (1995) disclosed modest induction of CYPs in Octupus pallidus digestive gland after exposure to known inducers like $\beta$-naphtoflavone and Aroclor, with increased activity of ethoxycoumarin-O-deethylase (ECOD) but not for ethoxyresorufin $O$-deethylase (EROD), which is one of the best accepted biomarkers of exposure to bioactive pollutants in vertebrates. This finding is in agreement with the work by Schlenk and Buhler (1988) with chitons, even though Semedo et al. (2014) found negligible activities of both enzymes in wild Octopus vulgaris. 


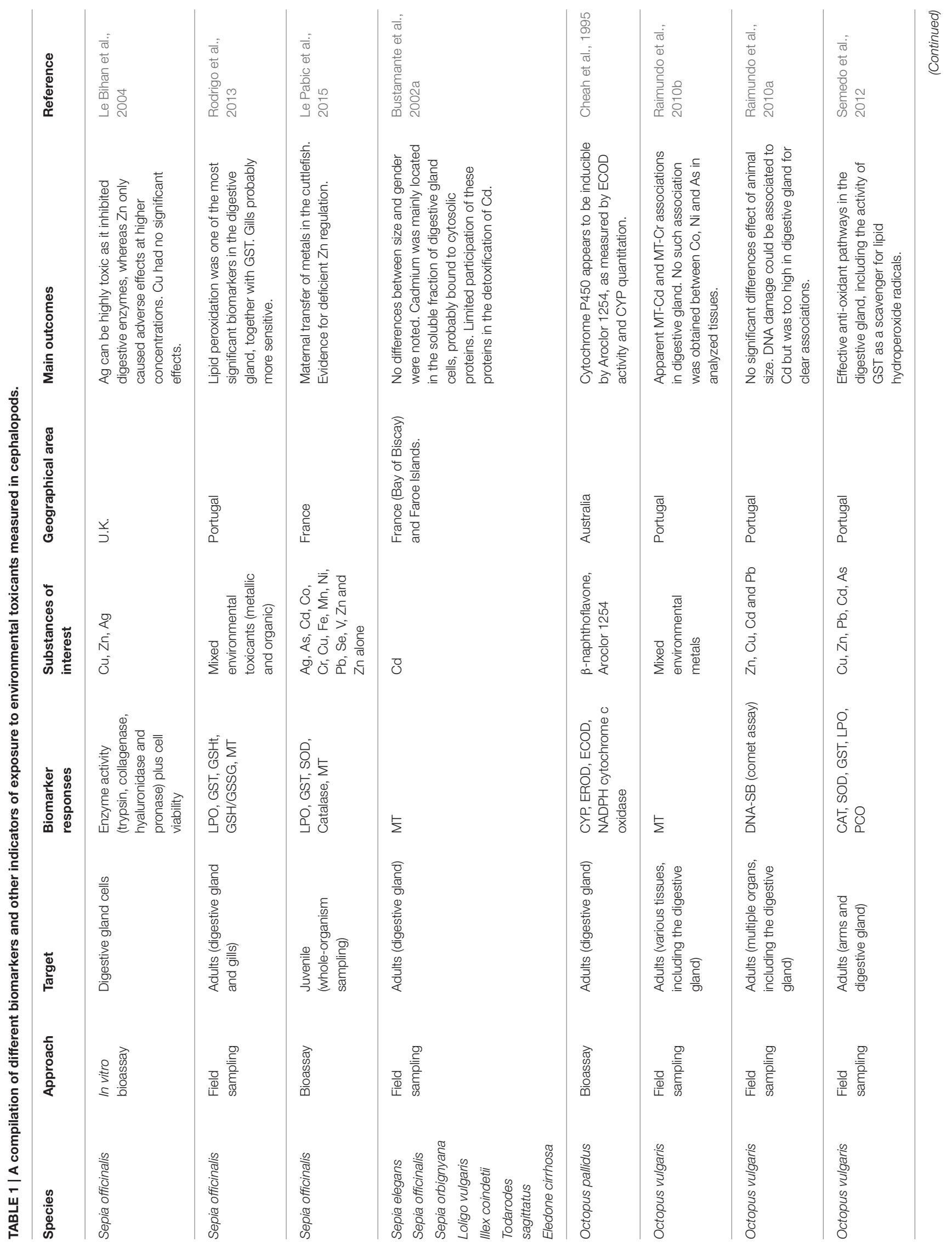


The activity of phase II enzymes, such as glutathione $S$ transferase or UDP-glucosyltransferase have been found in cephalopod digestive gland, with evidence that they can be induced by environmental toxicants but their specificity toward a specific class of substances has yet to be demonstrated (Schlenk and Buhler, 1988; Rodrigo et al., 2013; Le Pabic et al., 2015), since phase II enzymes can be induced by many factors, oxidative stress in particular. Inclusively, they were found to be promising targets in Octopus paralarvae exposed to metals (Nicosia et al., 2015). Altogether, less specific biomarkers, therefore responsive unspecific physiological challenge, yield more promising outcomes in the cephalopod digestive gland, among which are included superoxide dismutase (SOD) and catalase activities or glutathione induction (Semedo et al., 2012; Rodrigo et al., 2013; Nicosia et al., 2015). Note, though, that there are indications that the activity of oxidative stress enzymes can be significantly modulated by age in cephalopods (Zielinski and Pörtner, 2000). Interestingly, Oellermann et al. (2012) found that cuttlefish may adjust cardiac mitochondrial metabolism per se to adjust to thermal challenge, which indicates the ability to fine tune mitochondria-mediated oxidative functions under stress. This may explain the relevance of oxidative stress biomarkers in these animals, despite the missing link between mitochondrial function and toxicant-induced oxidative stress.

Another interesting target could be heat-shock proteins (HSPs) and similar chaperones that interfere with gene expression pathways. They have been described at the transcriptome level in several molluscs, including a few cephalopods (reviewed by Wang et al., 2013), and can be pointed as promising biomarkers (refer also to Oehlmann and Schulte-Oehlmann, 2003). In spite of the absence of similar work on cephalopods, with the exception of the work by Nicosia et al. (2015) with Octopus paralarvae (whose transcript levels increased with Cd exposure concentration), HSP70 induction has provided interesting results in other molluscs (bivalves in particular) subjected to several environmental stressors, from bacterial infection to metals, PAHs, pharmaceuticals, and biotoxins (Köhler et al., 1996; Boutet et al., 2003; Cellura et al., 2006; Song et al., 2006; Mello et al., 2012; Gust et al., 2013).

Altogether, detoxification of organic toxicants in the cephalopod digestive gland does occur, albeit potentially better adapted to dispose of toxins and unwanted by-products from feed and basal metabolism. It must also be considered that endpoints that are common biomarkers in vertebrates may not be the most adequate in molluscs, with particular respect to phase I. At the present, responses related to phase II and oxidative stress appear to be more viable biomarkers of exposure to bioactive organic toxicants, together with ECOD activity (refer to Table 1). Phase III of detoxification is still a subject of debate, being essentially reported for vertebrates, fish included. The action of specific transporters, like ATP-binding cassette (ABC) transporters, located in digestive tract cells, is described for the elimination of xenobiotic metabolites (reviewed by Ferreira et al., 2014). Even though not yet scrutinized in cephalopods, ABC transporters have been investigated in other molluscs and their action in gills during metal-induced challenge has already been reported (e.g., Della Torre et al., 2015). It would be of relevance 
to attempt to relate form and function of excretory vacuoles in digestive gland cells with phase III activity. Additionally, while the lack of genomic annotation is a clear drawback to unravel potentially novel mechanisms of detoxification through phases I to III in cephalopods, with the advent of state-of-the-art proteomics, metabolomics, (epi)genomics and transcriptomics tools (next-generation sequencing of genomic DNAs and RNAs), plus bioinformatics, more mechanistic information could be retrieved regarding detoxification pathways in cephalopods and other molluscs while assisting biomarker discovery.

\section{CONCLUDING REMARKS}

Even though it remains to be seen whether cephalopods can have such a significant role in biomonitoring as bivalves, the importance of these animals in ecosystem functioning, fisheries and more recently aquaculture dictates the relevance of investigating how these animals cope with anthropogenic pressures than endanger their habitats. The still scarce literature on physiological and molecular pathways related to detoxification of noxious substances suggests, however, that the digestive gland plays a major role, much in similarity with the vertebrate liver. As genomic annotation for these animals is slowly coupled with traditional biomarkers approaches that until recently were considered more or less exclusive to vertebrates,

\section{REFERENCES}

Bidder, A. M. (1966). "Feeding and digestion in cephalopods," in Physiology of Mollusca, Vol. 2, eds K. M. Wilbur and C. M. Yonge (New York, NY: Academic Press), 97-124.

Boucaud-Camou, E. (1968). Étude histologique et histochimique de l'appareil digestif de Sepiola atlantica D'Orbigny et Sepia officinalis L. Bull. Soc. Linn. Normandie 9, 220-243.

Boutet, I., Tanguy, A., Rousseau, S., Auffret, M., and Moraga, D. (2003). Molecular identification and expression of heat shock cognate 70 (hsc70) and heat shock protein 70 (hsp70) genes in the Pacific oyster Crassostrea gigas. Cell Stress Chaperon 8, 76-85. doi: 10.1379/1466-1268(2003)8\&lt;76:MIAEOH\&gt; 2.0.CO;2

Budelmann, B. U., Schipp, R., and Boletzky, S. (1997). “Cephalopoda”, in Mollusca II. Microscopic Anatomy of Invertebrates, Vol. 6A, eds F.W. Harrison, and A. Kohn (New York, NY: Wiley-Liss), 119-414.

Bustamante, P., Bertrand, M., Boucaud-Camou, E., and Miramand, P. (2006). Subcellular distribution of $\mathrm{Ag}, \mathrm{Cd}, \mathrm{Co} ., \mathrm{Cu}, \mathrm{Fe}, \mathrm{Mn}, \mathrm{Pb}$ and $\mathrm{Zn}$ in the digestive gland of the common cuttlefish Sepia officinalis. J. Shellfish Res. 25, 987-993. doi: 10.2983/0730-8000(2006)25[987:SDOACC]2.0.CO;2

Bustamante, P., Cosson, R. P., Gallien, I., Caurant, F., and Miramand, P. (2002a). Cadmium detoxification processes in the digestive gland of cephalopods in relation to accumulated cadmium concentrations. Mar. Environ. Res. 53, 227-241. doi: 10.1016/S0141-1136(01)00108-8

Bustamante, P., Grigioni, S., Boucher-Rodoni, R., Caurant, F., and Miramand, P. (2000). Bioaccumulation of 12 trace elements in the tissues of the nautilus Nautilus macromphalus from New Caledonia. Mar. Pollut. Bull. 40, 688-696. doi: 10.1016/S0025-326X(00)00005-9

Bustamante, P., Teyssié, J.-L., Fowler, S. W., Cotret, O., Danis, B., Miramand, P., et al. (2002b). Biokinetics of cadmium and zinc accumulation and depuration at different stages in the life cycle of the cuttlefish Sepia officinalis. Mar. Ecol. Prog. Ser. 231, 167-177. doi: 10.3354/meps 231167

Cellura, C., Toubiana, M., Parrinello, N., and Roch, P. (2006). HSP70 gene expression in Mytilus galloprovincialis hemocytes is triggered by moderate it may now be inferred that the toxicological pathways in cephalopods are more complex than expected for both metallic and organic xenobiotics, steering toward a new direction to understand the adaptative mechanisms of cephalopods to impacted marine ecosystems.

\section{AUTHOR CONTRIBUTIONS}

$\mathrm{AR}$ and $\mathrm{PC}$ are responsible for the conceptual design and writing of the manuscript. PC supervised the work.

\section{ACKNOWLEDGMENTS}

Part of this work was supported by the COST Action FA1301 "A network for improvement of cephalopod welfare and husbandry in research, aquaculture and fisheries (CephsInAction)". The authors are thankful to J. Raimundo (IPMA), S. Caeiro (CENSE), and M.H. Costa (MARE) for their support. The Portuguese Foundation for Science and Technology (FCT) is acknowledged for the funding for MARE through the strategic programme UID/MAR/04292/2013, plus the grants SFRH/BD/109462/2015 to AR and IF/00265/2015 to PC. The research project GreenTech (PTDC/MARBIO/0113/2014), also funded by FCT, is acknowledged as well.

heat shock and Vibrio anguillarum, but not by $V$. splendidus or Micrococcus lysodeikticus. Dev. Comp. Immunol. 30, 984-997. doi: 10.1016/j.dci.2005.12.009 Châtel, A., Faucet-Marquis, V., Perret, M., Gourlay-Francé, C., Uher, E., PfohlLeszkowicz, A., et al. (2012). Genotoxicity assessment and detoxification induction in Dreissena polymorpha exposed to benzo[a]pyrene. Mutagenesis 27, 703-711. doi: 10.1093/mutage/ges036

Chaty, S., Rodius, F., and Vasseur, P. (2004). A comparative study of the expression of CYP1A and CYP4 genes in aquatic invertebrate (freshwater mussel, Unio tumidus) and vertebrate (rainbow trout, Oncorhynchus mykiss). Aquat. Toxicol. 69, 8-93. doi: 10.1016/j.aquatox.2004.04.011

Cheah, D. M. Y., Wright, P. F. A., Holdway, D. A., and Ahokas, J. T. (1995). Octopus pallidus cytochrome P-450: characterization and induction studies with $\beta$-naphthoflavone and Arochlor 1254. Aquat. Toxicol. 33, 201-214. doi: 10.1016/0166-445X(95)00014-U

Costa, P. M., Rodrigo, A. P., and Costa, M. H. (2014). Microstructural and histochemical advances on the digestive gland of the common cuttlefish, Sepia officinalis L. Zoomorphology 133, 59-69. doi: 10.1007/s00435-013-0201-8

Costa, P. R., Botelho, M. J., and Rodrigues, S. M. (2009). Accumulation of paralytic shellfish toxins in digestive gland of Octopus vulgaris during bloom events including the dinoflagellate Gymnodinium catenatum. Mar. Pollut. Bull. 58, 1739-1765. doi: 10.1016/j.marpolbul.2009.08.005

Costa, P. R., Rosa, R., Duarte-Silva, A., Brotas, V., and Sampayo, M. A. (2005). Accumulation, transformation and tissue distribution of domoic acid, the amnesic shellfish poisoning toxin, in the common cuttlefish, Sepia officinalis. Aquat. Toxicol. 74, 82-91. doi: 10.1016/j.aquatox.2005.01.011

Cuénot, L. (1907). Fonctions absorbante et excrétrice du foie des céphalopodes. Arch. Zool. Exp. Gen. 4, 227-245.

Danis, B., Bustamante, P., Cotret, O., Teyssié, J.-L., Fowler, S. W., and Warnau, M. (2005). Bioaccumulation of PCBs in the cuttlefish Sepia officinalis from seawater, sediment and food pathways. Environ. Pollut. 134, 113-122. doi: 10.1016/j.envpol.2004.07.010

Della Torre, C., Balbi, T., Grassi, G., Frenzilli, G., Bernardeschi, M., Smerilli, A., et al. (2015). Titanium dioxide nanoparticles modulate the toxicological response to cadmium in the gills of Mytilus galloprovincialis. J. Hazard. Mater. 297, 92-100. doi: 10.1016/j.jhazmat.2015.04.072 
Ferreira, M., Costa, J., and Reis-Henriques, M. A. (2014). ABC transporters in fish species: a review. Front. Physiol. 5:266. doi: 10.3389/fphys.2014.00266

Finger, J., and Smith, J. (1987). Molecular association of $\mathrm{Cu}, \mathrm{Zn}, \mathrm{Cd}$ and ${ }^{210} \mathrm{Po}$ in the digestive gland of the squid Nototodarus gouldi. Mar. Biol. 95, 87-91. doi: 10.1007/BF00447489

Frenzel, J. H. (1886). Mikrographie der Mitteldarmdrüse (Leber) der Mollusken. Erster Theil. Allgemeine Morphologie und Physiologie des Drüsenepithels. Nova Acta Ksl. Leop. Carol. Deutsch. Akad. Naturf. 48, 81-296.

Galli, A., Del Chiaro, D., Nieri, R., and Bronzetti, G. (1988). Studies on cytochrome P450 in Mytilus galloprovincialis: induction by Na-phenobarbital and ability to biotransform xenobiotics. Mar. Biol. 100, 69-73. doi: 10.1007/BF00392956

Gust, M., Fortier, M., Garric, J., Fournier, M., and Gagné, F. (2013). Effects of short-term exposure to environmentally relevant concentrations of different pharmaceutical mixtures on the immune response of the pond snail Lymnaea stagnalis. Sci. Total Environ. 445-446, 210-218. doi: 10.1016/j.scitotenv.2012.12.057

Köhler, H. R., Rahman, B., Graft, S., Berkus, M., and Triebskorn, R. (1996). Expression of the stress-70 protein family (HSP70) due to heavy metal contamination in the slug, Deroceras reticulatum: an approach to monitor sublethal stress conditions. Chemosphere 33, 1327-1340. doi: 10.1016/0045-6535(96)00270-6

Larguinho, M., Cordeiro, A., Diniz, M. S., Costa, P. M., and Baptista, P. V. (2014). Metabolic and histoathological alterations in the marine bivalve Mytilus galloprovincialis induced by chronic exposure to acrylamide. Environ. Res. 135, 55-62. doi: 10.1016/j.envres.2014.09.004

Le Bihan, E., Perrin, A., and Koueta, N. (2004). Development of a bioassay from isolated digestive gland cells of the cuttlefish Sepia officinalis L. (Mollusca Cephalopoda): effect of $\mathrm{Cu}, \mathrm{Zn}$, and $\mathrm{Ag}$ on enzymes activities and cell viability. J. Exp. Mar. Biol. Ecol. 309, 47-66. doi: 10.1016/j.jembe.2004.03.007

Le Pabic, C., Caplat, C., Lehodey, J.-P., Milinkovitch, T., Koueta, N., Cosson, R. P., et al. (2015). Trace metal concentrations in post-hatching cuttlefish Sepia officinalis and consequences of dissolved zinc exposure. Aquat. Toxicol. 159, 23-35. doi: 10.1016/j.aquatox.2014.11.012

Livingstone, D. R. (1994). Recent developments in marine invertebrate organic xenobiotic metabolism. TEN 1, 88894.

Lobo, J., Costa, P. M., Caeiro, S., Martins, M., Ferreira, A. M., Caetano, M., et al. (2010). Evaluation of the potential of the common cockle (Cerastoderma edule L.) for the ecological risk assessment of estuarine sediments: bioaccumulation and biomarkers. Ecotoxicology 19, 1496-1512. doi: 10.1007/s10646-010-0535-7

Mangold, K. (1983). Food, feeding and growth in cephalopods. Mem. Natl. Mus. Vic. 44, 81-93.

Martinez, R., López-Ripoll, E., Avila-Poveda, O., Santos-Ricalde, R., Mascaró, M., and Rosas, C. (2011). Cytological ontogeny of the digestive gland in posthatching Octopus maya, and cytological background of digestion in juveniles. Aquat. Biol. 11, 249-261. doi: 10.3354/ab00305

Martoja, M., and Marcaillou, C. (1993). Localisation cytologique du cuivre et de quelques autres métaux dans la glande digestive de la seiche, Sepia officinalis L. (Mollusque Céphalopode). Can. J. Fish. Aquat. Sci. 50, 542-550. doi: 10.1139/f93-063

Mello, D. F., de Oliveira, E. S., Vieira, R. C., Simões, E., Trevisan, R., Dafre, A. L., et al. (2012). Cellular and transcriptional responses of Crassostrea gigas hemocytes exposed in vitro to brevetoxin (PbTx-2). Mar. Drugs 10, 583-597. doi: $10.3390 / \mathrm{md} 10030583$

Miramand, P., and Bentley, D. (1992). Concentration and distribution of heavy metals in tissues of two cephalopods, Eledone cirrhosa and Sepia officinalis, from the French coast of the English Channel. Mar. Biol. 114, 407-414. doi: 10.1007/BF00350031

Nicosia, A., Salamone, M., Mazzola, S., and Cutitta, A. (2015). Transcriptional and biochemical effects of cadmium and manganese on the defense system of Octopus vulgaris paralarvae. Biomed. Res. Int. 2015:437328. doi: 10.1155/2015/437328

Oehlmann, J., and Schulte-Oehlmann, U. (2003). "Molluscs as bioindicators," in Trace Metals and Other Contaminants in the Environment, Vol. 6, eds B. A. Markert, A. M. Breure, and H. G. Zechmeister (Amsterdam: Elsevier), 577-635.

Oellermann, M., Pörtner, H. O., and Mark, F. C. (2012). Mitochondrial dynamics underlying thermal plasticity of cuttlefish (Sepia officinalis) hearts. J. Exp. Biol. 215, 2992-3000. doi: 10.1242/jeb.068163
Penicaud, V., Lacoue-Labarthe, T., and Bustamante, P. (2017). Metal bioaccumulation and detoxification processes in cephalopods: a review. Environ. Res. 155, 123-133. doi: 10.1016/j.envres.2017.02.003

Pereira, P., Raimundo, J., Vale, C., and Kadar, E. (2009). Metal concentrations in digestive gland and mantle of Sepia officinalis from two coastal lagoons of Portugal. Sci. Total Environ. 407, 1080-1088. doi: 10.1016/j.scitotenv.2008.10.023

Pernice, M., Boucher, J., Boucher-Rodoni, R., Joannot, P., and Bustamante, P. (2009). Comparative bioaccumulation of trace elements between Nautilus pompilius and Nautilus macromphalus (Cephalopoda: Nautiloidea) from Vanuatu and New Caledonia. Ecotoxicol. Environ. Safe 72, 365-371. doi: 10.1016/j.ecoenv.2008.04.019

Raimundo, J., Caetano, M., and Vale, C. (2004). Geographical variation and partition of metals in tissues of Octopus vulgaris along the Portuguese coast. Sci. Total Environ. 325, 71-81. doi: 10.1016/j.scitotenv.2003.12.001

Raimundo, J., Costa, P. M., Vale, C., Costa, M. H., and Moura, I. (2010b). Metallothioneins and trace elements in digestive gland, gills, kidney and gonads of Octopus vulgaris. Comp. Biochem. Physiol. C 152, 139-146. doi: 10.1016/j.cbpc.2010.03.009

Raimundo, J., Pereira, P., Vale, C., and Caetano, M. (2005). Fe, Zn, Cu and Cd in the digestive gland and muscle tissues of Octopus vulgaris and Sepia officinalis from coastal areas in Portugal. Cienc. Mar. 31, 243-251. doi: 10.7773/cm.v31i12.91

Raimundo, J., Vale, C., Duarte, R., and Moura, I. (2010a). Association of Zn, $\mathrm{Cu}, \mathrm{Cd}$ and $\mathrm{Pb}$ with protein fractions and sub-cellular partitioning in the digestive gland of Octopus vulgaris living in habitats with different metal levels. Chemosphere 81, 1314-1319. doi: 10.1016/j.chemosphere.2010.08.029

Richter, I., and Fidler, A. E. (2014). Marine invertebrate xenobiotic-activated nuclear receptors: their application as sensor elements in high-throughput bioassays for marine bioactive compounds. Mar. Drugs 12, 5590-5618. doi: $10.3390 / \mathrm{md} 12115590$

Rodrigo, A. P., Costa, P. M., Costa, M. H., and Caeiro, S. (2013). Integration of sediment contamination with multi-biomarker responses in a novel bioindicator candidate (Sepia officinalis) for risk assessment in impacted estuaries. Ecotoxicology 22, 1538-1554. doi: 10.1007/s10646-013-1140-3

Schlenk, D., and Buhler, D. R. (1988). Cytochrome P-450 and phase II activities in the gumboot chiton Cryptochiton stelleri. Aquat. Toxicol. 13, 167-182. doi: 10.1016/0166-445X(88)90041-0

Seixas, S., Bustamante, P., and Pierce, G. J. (2005). Accumulation of mercury in the tissues of the common octopus Octopus vulgaris (L.) in two localities on the Portuguese coast. Sci. Total Environ. 340, 113-122. doi: 10.1016/j.scitotenv.2004.08.012

Semedo, M., Oliveira, M., Gomes, F., Reis-Henriques, M. A., Delerue-Matos, C., Morais, S., et al. (2014). Seasonal patterns of polycyclic aromatic hydrocarbons in digestive gland and arm of octopus (Octopus vulgaris) from the Northwest Atlantic. Sci. Total Environ. 481, 488-497. doi: 10.1016/j.scitotenv.2014.02.088

Semedo, M., Reis-Henriques, M. A., Rey-Salgueiro, L., Oliveira, M., DelerueMatos, C., Morais, S., et al. (2012). Metal accumulation and oxidative stress biomarkers in octopus (Octopus vulgaris) from Northwest Atlantic. Sci. Total Environ. 433, 230-237. doi: 10.1016/j.scitotenv.2012.06.058

Semmens, J. M. (2002). Changes in the digestive gland of the loliginid squid Sepioteuthis lessoniana (Lesson, 1830) associated with feeding. J. Exp. Mar. Biol. Ecol. 274, 19-39. doi: 10.1016/S0022-0981(02)00165-X

Snyder, M. J. (2000). Cytochrome P450 enzymes in aquatic invertebrates: recent advances and future directions. Aquat. Toxicol. 48, 529-547. doi: 10.1016/S0166-445X(00)00085-0

Song, L. S., Xu, W., Li, C. H., Li, H. L., Wu, L. T., Xiang, J. H., et al. (2006). Development of expressed sequence tags from the bay scallop, Argopecten irradians. Mar. Biotechnol. 8, 161-169. doi: 10.1007/s10126-0050126-4

Storelli, M. M., Barone, G., Daddabbo, R., and Marcotrigiano, G. O. (2006). Concentrations and composition of organochlorine contaminants in different species of cephalopod molluscs from the Italian waters (Adriatic Sea). Chemosphere 64, 129-134. doi: 10.1016/j.chemosphere.2005.10.037

Swift, K., Johnston, D., and Moltschaniwskyj, N. (2005). The digestive gland of the southern dumpling squid (Euprymna tasmanica): structure and function. J. Exp. Mar. Biol. Ecol. 315, 177-186. doi: 10.1016/j.jembe.2004. 09.017 
Volland, J.-M., Lechaire, J.-P., Frebourg, G., Aranda, D. A., Ramdine, G., and Gros, O. (2012). Insight of EDX analysis and EFTEM: Are spherocrystals located in Strombidae digestive gland implied in detoxification of trace metals? Microsc. Res. Tech. 75, 425-432. doi: 10.1002/jemt. 21073

Wang, L., Yang, C., and Song, L. (2013). The molluscan HSP70s and their expression in hemocytes. Invertebrate Surviv. J. 10, 77-83.

Zaldidar, B., Cancio, I., Soto, M., and Marigómez, I. (2007). Digestive cell turnover in digestive gland epithelium of slugs experimentally exposed to a mixture of cadmium and kerosene. Chemosphere 70, 144-154. doi: 10.1016/j.chemosphere.2007.06.071

Zielinski, S., and Pörtner, H.-O. (2000). Oxidative stress and antioxidative defense in cephalopods: a function of metabolic rate or age? Comp. Biochem.
Physiol. B Biochem. Mol. Biol. 125, 147-160. doi: 10.1016/S0305-0491(99) 00162-5

Conflict of Interest Statement: The authors declare that the research was conducted in the absence of any commercial or financial relationships that could be construed as a potential conflict of interest.

Copyright (c) 2017 Rodrigo and Costa. This is an open-access article distributed under the terms of the Creative Commons Attribution License (CC BY). The use, distribution or reproduction in other forums is permitted, provided the original author(s) or licensor are credited and that the original publication in this journal is cited, in accordance with accepted academic practice. No use, distribution or reproduction is permitted which does not comply with these terms. 